\title{
New data on the rare snail Soosia diodonta (A. Ferussac, 1821) (Gastropoda: Helicodontidae) in Bulgaria
}

\author{
Ivaylo Dedov ${ }^{1}$, Dilian Georgiev ${ }^{2}$, Ulrich E. Schneppat ${ }^{3}$, Fabia Knechtle Glogger ${ }^{4}$
}

(1) Institute of Biodiversity and Ecosystem Research, Bulgarian Academy of Sciences, 2 Gagarin Street, 1113 Sofia, Bulgaria, idedov@gmail.com

(2) Department of Ecology and Environmental Conservation, University of Plovdiv, Tsar Assen Street 24, 4000 Plovdiv, Bulgaria, diliangeorgiev@gmail.com; https://orcid.org/0000-0003-2885-4895

(3) Sennereiweg 8, CH-7074 Churwalden-Malix, Switzerland, u.schneppat@gmail.com

(4) Naturmanagement, Sturzenegg 2147, CH-9100 Herisau, Switzerland, naturmanagement@knechtleglogger.ch

\begin{abstract}
In the present article, we summarised all known information on the species Soosia diodonta (A. Ferussac, 1821) from Bulgaria. A new locality in urban environment, photos of live animals and the reproductive system of the species are given. New information on its ecology and biology is provided.
\end{abstract}

Keywords: biology, Bulgaria, distribution, ecology, Soosia diodonta

\section{Introduction}

The snail Soosia diodonta (A. Ferussac, 1821) was described by Férussac in 1821 from Banat, Romania as Helix diodonta (Férussac A. \& Deshayes, 1819-1851). Based on the anatomical features Hesse (1918) placed the species in a separate genus, Soosia Hesse, 1918. Presently, $S$. diodonta is the only member of the genus (Schileyko, 2006; Bank \& Neubert, 2017). Soosia diodonta is reported for the first time for Bulgaria, after only one live specimen, by Urbanski (1964) from the Vitosha Mountains, Boyana Waterfall area. Despite the collecting efforts during the last 25 years in the area of the waterfall, the species has not been confirmed again. Georgiev \& Stoycheva (2007) reported S. diodonta from a new locality in the Eastern Balkan Mountains, western of Kotel Town.

Outside Bulgaria, the species is found in the southern Carpathians, in the Western Balkan Mountains (eastern Serbia) and in the lowlands of the Lower Danube River. There are only a few known locations, summarised by Fehér (2020): Moldova Noua, Baile
Herculane, Padurea Caldarusani, Jurilofca; Padurea Prahova, Surdulica; Cerna valley, Motru Sec, Closani, Tismana and Nera gorge near Sasca Montana.

In the present article, new information is given about the distribution and biology of the Bulgarian population of the species, as well as pictures of the reproductive system and live animals in situ.

\section{Material and methods}

The snail was collected from two localities in the region of the Balkan Mountains: 1) western of Kotel, road to Zelenich area (Fig. 1); 2) Tryavna, in the town, ruins (Fig. 2). The type of habitats is determined according the Council Directive 92/43/92 and the EUNIS habitat classification. Both literature and new distribution data of the species $S$. diodonta in Bulgaria are summarised in Table 1. The snails were hand collected and photographed in situ. Some species were killed, fixed and stored in $75 \%$ ethanol for further analyses. Abbreviation used: Coll. ID = identification number in the 
Ivaylo Dedov, Dilian Georgiev, Ulrich E. Schneppat, Fabia Knechtle Glogger

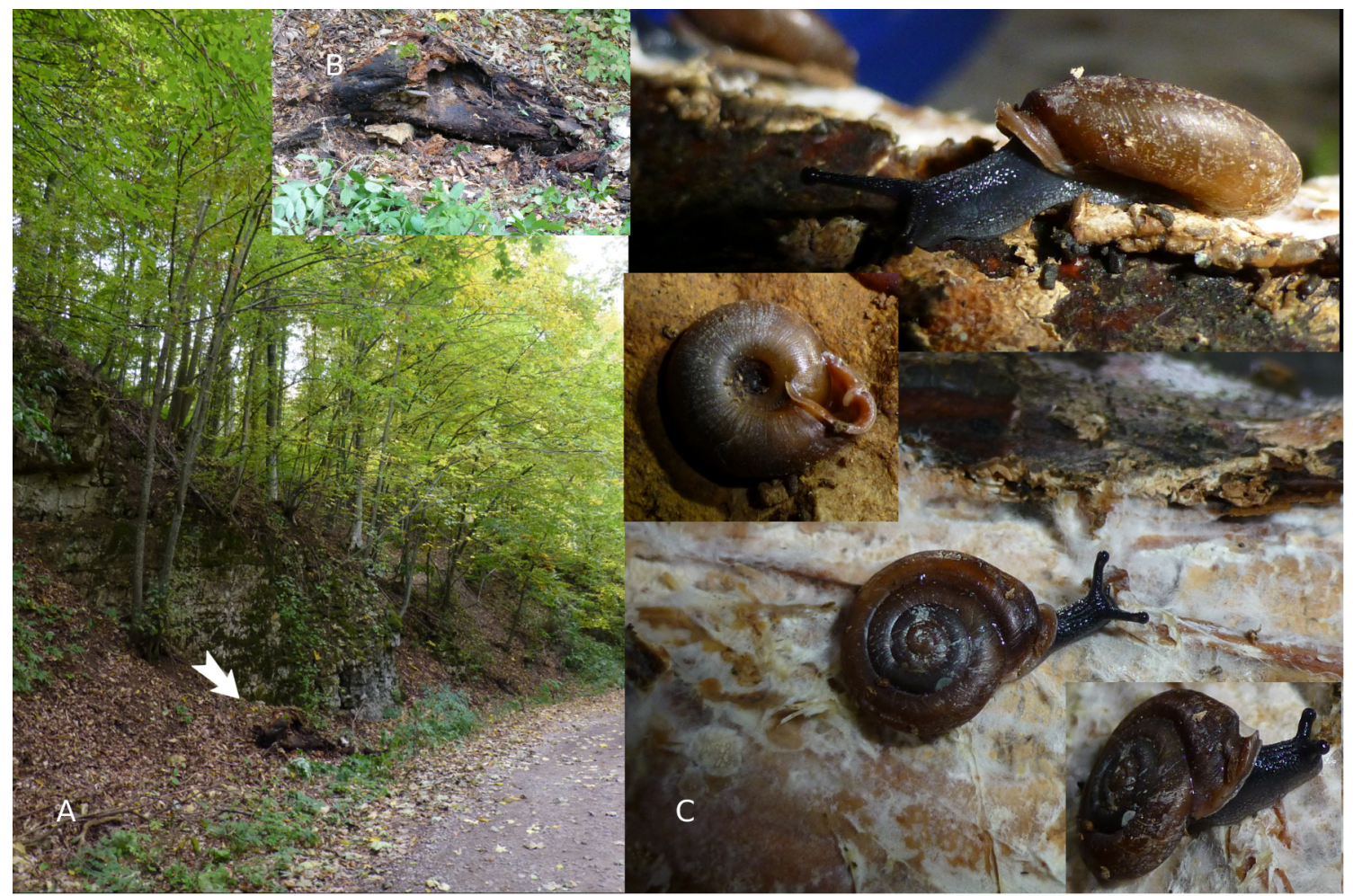

Fig. 1. The locality of S. diodonta after Kotel Town, road to Zelenich area and in situ photos of live animals. A - the habitat of the species and the location of the specimens under $\log (\mathrm{B}) ; \mathrm{C}-$ live specimens from Zelenich.

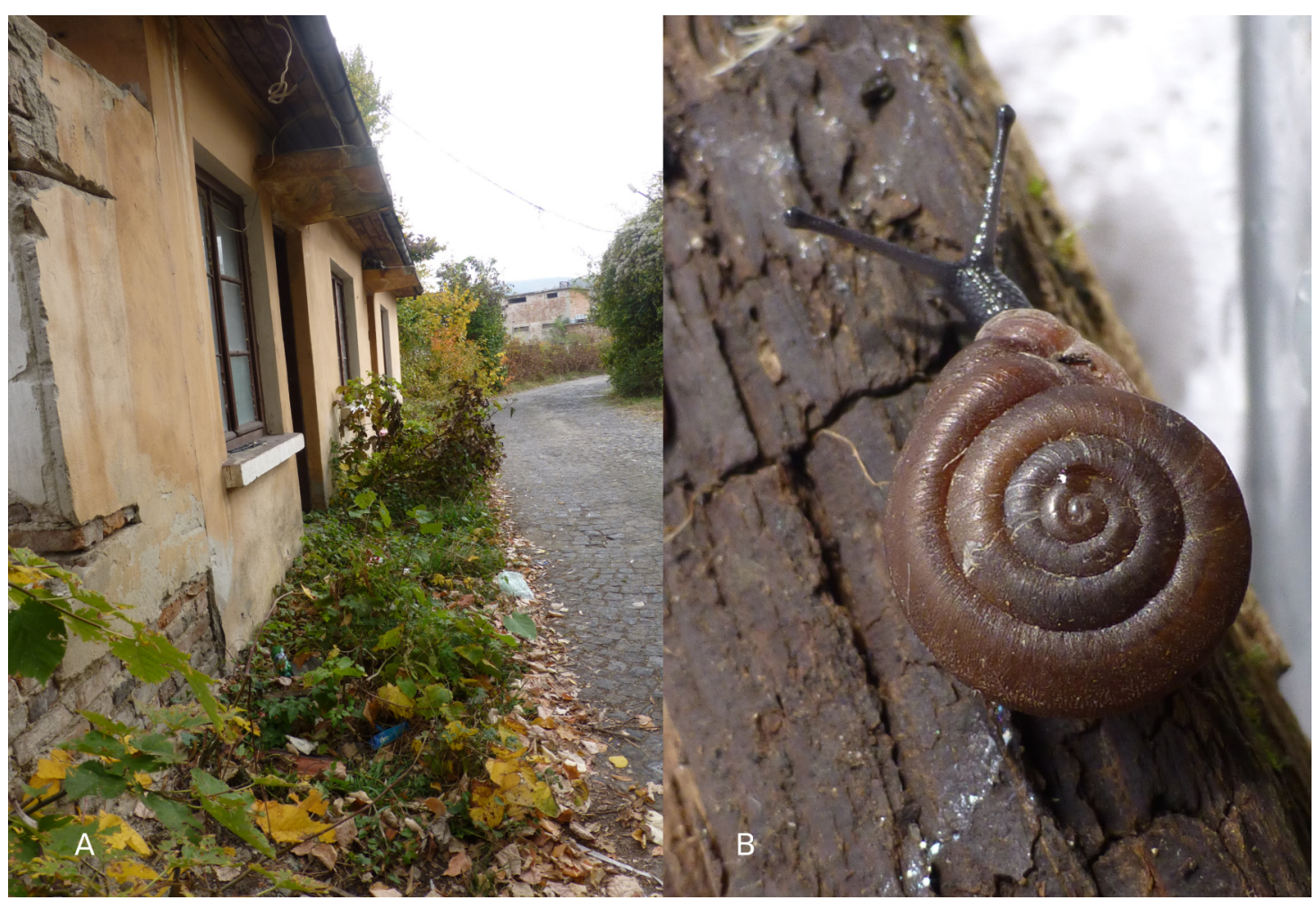

Fig. 2. The locality of S. diodonta in Tryavna Town and in situ photos of live animal. A - the urban habitat of the species; B live specimens from Tryavna Town. 
Table 1. Localities of $S$. diodonta in Bulgaria.

\begin{tabular}{|c|c|c|c|c|}
\hline Geographic Region & Locality & Habitat & $\begin{array}{l}\text { Date, collectors/ } \\
\text { observers/collection }\end{array}$ & $\begin{array}{l}\text { GPS coordinates, } \\
\text { altitude, remarks }\end{array}$ \\
\hline Vitosha Mountains & Boyana Waterfall & $\begin{array}{l}\text { Asperulo-Fagetum beech } \\
\text { forests }(9130)\end{array}$ & Urbanski (1964) & $\begin{array}{l}\mathrm{N} 42.6295^{\circ} \mathrm{E} 023.2542^{\circ}, \\
1303 \mathrm{~m} \text { a.s.l. (restored) }\end{array}$ \\
\hline $\begin{array}{l}\text { Eastern Balkan } \\
\text { Mountains }\end{array}$ & $\begin{array}{l}\text { W of Kotel (road to } \\
\text { Zelenich area) }\end{array}$ & $\begin{array}{l}\text { Medio-European limestone } \\
\text { beech forests of the } \\
\text { Cephalanthero Fagion } \\
(9150)\end{array}$ & $\begin{array}{l}\text { Georgiev \& Stoycheva } \\
\text { (2007) }\end{array}$ & $\begin{array}{l}\mathrm{N} 42.8866^{\circ} \text { E026.3943 } \\
612 \mathrm{~m} \text { a.s.l. (restored) }\end{array}$ \\
\hline ditto & $\begin{array}{l}\text { W of Kotel (road to } \\
\text { Zelenich area) }\end{array}$ & $\begin{array}{l}\text { Medio-European limestone } \\
\text { beech forests of the } \\
\text { Cephalanthero Fagion } \\
(9150)\end{array}$ & $\begin{array}{l}\text { 12.X.2013, leg. U. } \\
\text { Schneppat, F. Knetche, } \\
\text { D. Georgiev, I. Dedov, } \\
\text { 2adl, 1jvd (IBER, } \\
\text { Coll.No.1642) }\end{array}$ & $\begin{array}{l}\mathrm{N} 42.88248^{\circ} \\
\mathrm{E} 026.38868^{\circ}, 625 \mathrm{~m} \\
\text { a.s.1. (original) }\end{array}$ \\
\hline $\begin{array}{l}\text { Central Balkan } \\
\text { Mountains }\end{array}$ & Tryavna, in the town & $\begin{array}{l}\text { Urban and suburban } \\
\text { derelict spaces - ruderal } \\
\text { communities of Sambucus } \\
\text { ebulus, Humulus lupulus, } \\
\text { Rubus caesius, Clematis } \\
\text { vitalba etc. (J1.51), under } \\
\text { tiles }\end{array}$ & $\begin{array}{l}\text { 14.X.2013, leg. U. } \\
\text { Schneppat, F. Knetche, } \\
\text { I. Dedov, D. Georgiev } \\
\text { 12adl, 2jvd (IBER, } \\
\text { Coll.No.1645) }\end{array}$ & $\begin{array}{l}\mathrm{N} 42.872037^{\circ} \\
\mathrm{E} 025.497549^{\circ}, 432 \mathrm{~m} \\
\text { a.s.1. (original) }\end{array}$ \\
\hline
\end{tabular}

molluscs collection of the Institute of Biodiversity and Ecosystem Research, Bulgarian Academy of Sciences, Sofia.

\section{Results}

Distribution in Bulgaria

In Bulgaria, the species is considered to be rare. Presently, the species is known from three localities: one in the Vitosha Mountains (Fig. 3) and two in the region of the Balkan Mountains (Table 1) (Urbanski, 1964; Georgiev \& Stoycheva, 2007; present article). Despite the collecting efforts, the species was not found again in the area of the Boyana Waterfall, Vitosha Mountains. The new locality is in the town of Tryavna, in the region of the Central Balkan Mts.

\section{Ecology}

In Bulgaria, the species was found in: 1) Asperulo-Fagetum beech forests (9130) (Council Directive 92/43/92), near Boyana Waterfall (Urbanski, 1964), 2) Medio-European limestone beech forests of the Cephalanthero Fagion (9150) (Council Directive 92/43/92), near Kotel (Georgiev \& Stoycheva, 2007) and 3)

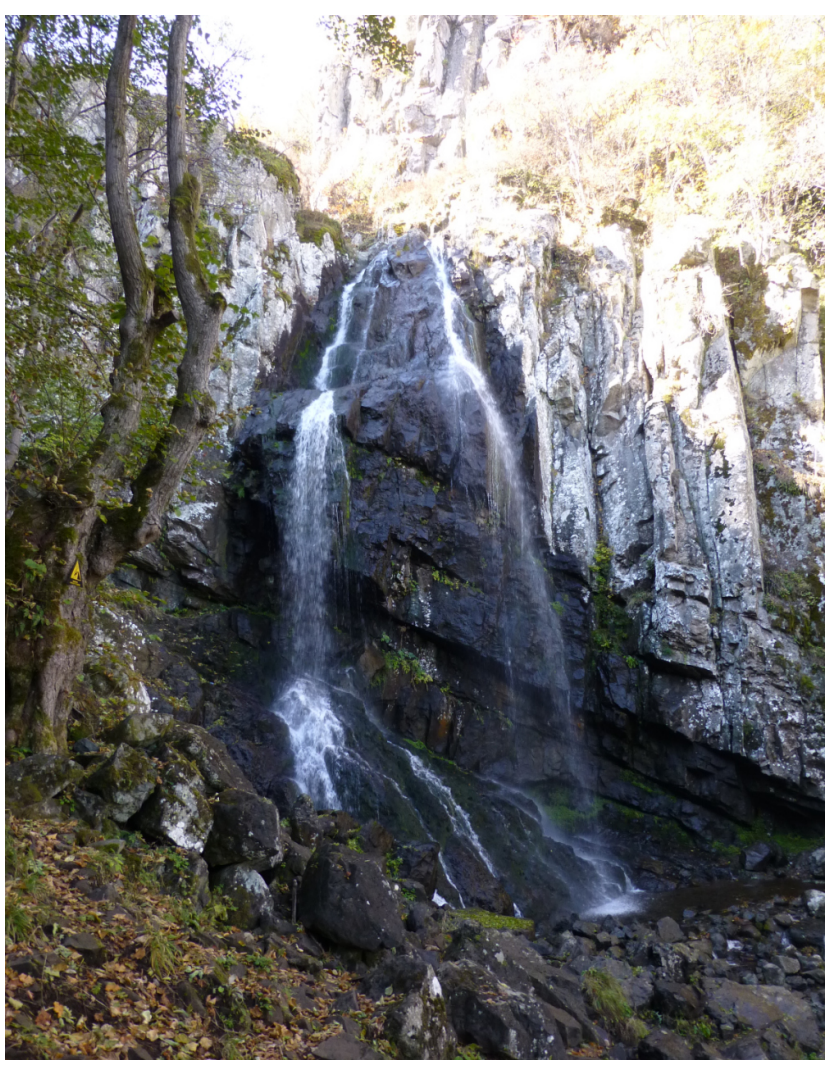

Fig. 3. The area of Boyana Waterfall, Vitosha Mountains the first reported locality of $S$. diodonta for Bulgaria by Urbanski (1964). 


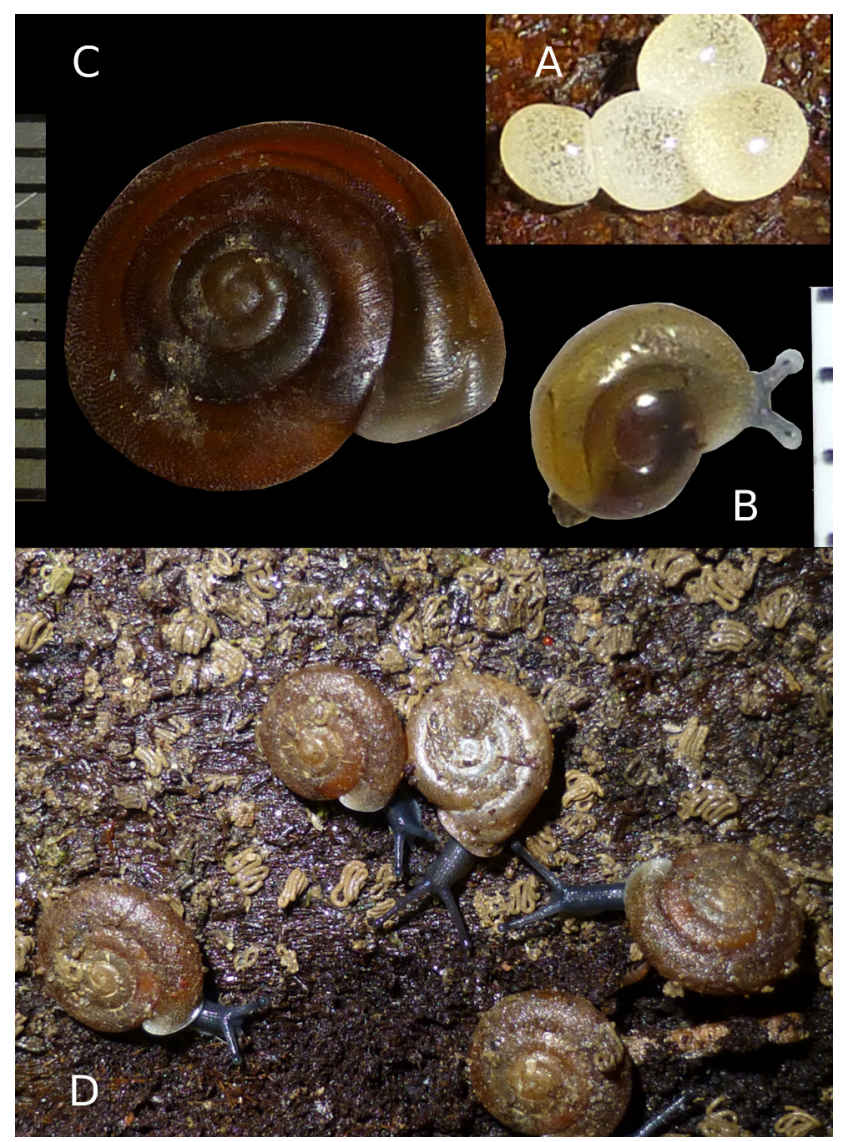

Fig. 4. S. diodonta - eggs (A), offspring (B) and adults from the terrarium of F. K. Glogger - shell (C) and live specimens (D).

Urban and suburban derelict spaces - ruderal communities of Sambucus ebulus, Humulus lupulus, Rubus caesius, Clematis vitalba etc. (J1.51) (EUNIS habitat classification), in the town of Tryavna, under tiles (Figs 1-3). The species prefers shady places - under bark, in old trunks, under tiles and other materials, which provide it with good humidity.

\section{Biology}

The biology of $S$. diodonta was studied keeping specimens in terrarium (for more details about the conditions in the terrarium and the used food see Table 2). Similarly to many other gastropod species, $S$. diodonta is active at night. The pre-copulation habits and copulation activity were not observed. The first eggs were laid about 20 days (D. Georgiev) and 3.5 months (F. K. Glogger) after the collecting of the adult specimens from Tryavna Town (most probably, the specimens grown by D. Georgiev were taken from nature fertil-

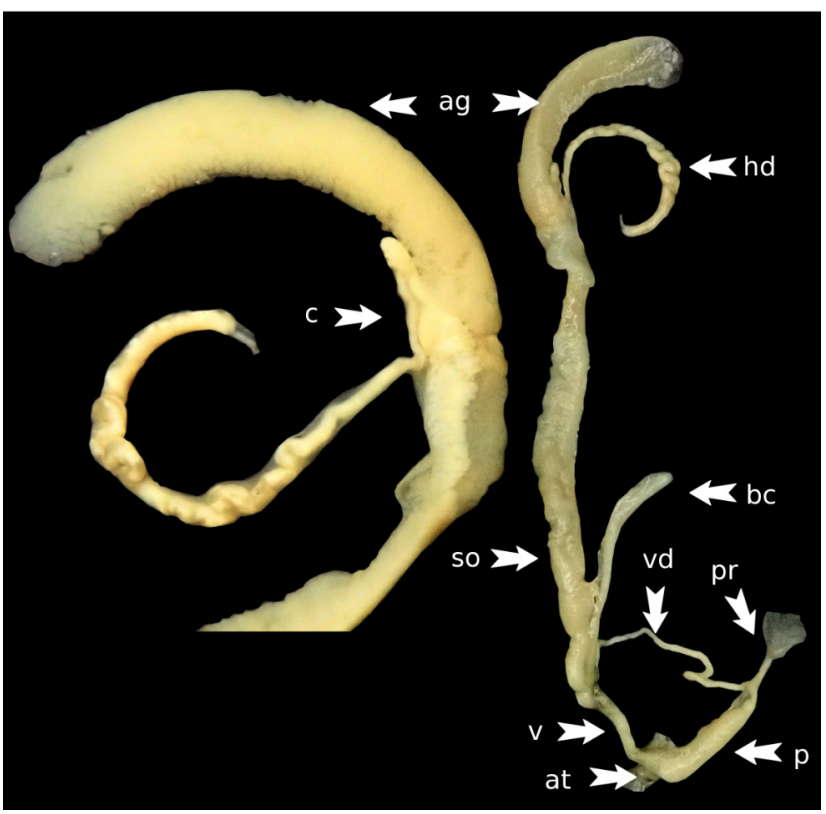

Fig. 5. S. diodonta, reproductive system. Abbreviations: $\hat{\jmath} q$ at - atrium; $\widehat{\delta}: \mathrm{p}$ - penis, $\mathrm{pr}$ - penial retractor, vd - vas defferens; + : v - vagina, so - sperm-oviduct, ag - albumen gland, c - carrefour, hd - hermaphroditic duct, bc - bursa copulatrix; ad - adult, juv - juvenile, add - adult empty shell, adl - adult collected alive, juvd - juvenile empty shell, juvl juvenile collected alive.

ised, while the specimens of F. K. Glogger copulated in the terrarium). The eggs were laid in clutches (3-5 eggs in groups, mostly 3-4 eggs together), adhered to the substrate. The eggs were round-elliptic (about $2.5 \times 1.5$ $\mathrm{mm}$ ), milky-whitish, looking dotted. The period from the eggs-laying to hatching was 15-20 days (F. K. Glogger) and 22 days (D. Georgiev). The freshly hatched offspring were with 2 whorls and a size of about $2 \mathrm{~mm}$. It took about 5 months for the offspring to turn into adults (Fig. 4).

Shells

The investigated shells correspond perfectly with the description of Schileyko (2006) and demonstrated stable characters in shell colour and shape (Grossu, 1983). According to Schileyko (2006), the shell is nearly flat, discoidal, rather thin, of 4.5 scarcely convex whorls. Last whorl distinctly angulate, descending in front, constricted at aperture and impressed above. Colour brownish-corneous. Embryonic whorls smooth, the rest of the surface minutely granularly striate. Aperture narrow, very oblique; margins reflexed, with 1 parietal 
Table 2. Biology of S. diodonta.

\begin{tabular}{|c|c|c|}
\hline & F. K. Glogger -5 spm & D. Georgiev - 2 spm \\
\hline Size of terrarium (cm) & $60 \times 70 \times 60$ & $10 \times 15 \times 12$ \\
\hline Type of substrate & $\begin{array}{l}\text { Soil - mixed (brown forest soil, and sort of } \\
\text { terrarium soil) with wood (some branches and } \\
\text { bark), leaves, moss }\end{array}$ & Carbonate soil \\
\hline Temperature regime & Summer $18-19^{\circ} \mathrm{C}$, Winter $13-15^{\circ} \mathrm{C}$ & No observations \\
\hline Moisture regime & $\begin{array}{l}\text { Regularly sprayed rainwater in the terrarium to } \\
\text { keep it moist }\end{array}$ & Keep it moist \\
\hline $\begin{array}{l}\text { Type of food, food } \\
\text { preferences }\end{array}$ & $\begin{array}{l}\text { Old leaves, Cucumis sativus L., Cucurbita pepo L. } \\
\text { var. zucchini, Daucus carota L., mushrooms. } \\
\text { Prefered mushrooms. }\end{array}$ & $\begin{array}{l}\text { Daucus carota subsp. sativus (Hoffm.) Schübl. \& } \\
\text { G. Martens, Brassica oleracea L., Capsicum } \\
\text { annuum L., Cucumis sativus L.; fruits: Malus } \\
\text { domestica Borkh., 1803; green leaves of grass } \\
\text { species: Trifolium sp., Petunia sp.; and mushroom } \\
\text { fruiting bodies: Calvatia sp. }\end{array}$ \\
\hline Round-the-clock activity & $\begin{array}{l}\text { No detailed observations. Always active in the } \\
\text { period } 21.00-23.00 \mathrm{~h} \text {. During the daytime they } \\
\text { were most time hidden behind a piece of bark (in } \\
\text { group). }\end{array}$ & $\begin{array}{l}5 \text { November 2013: the adult snails are always under } \\
\text { the leafs, even in the early morning; } 9 \text { November } \\
\text { 2013: one adult is on the wall of the terrarium at } \\
\text { around } 19 \text { h, full darkness; } 10 \text { November } 2013 \text { : } \\
\text { eating carrot during the night, T 18.4C. }\end{array}$ \\
\hline $\begin{array}{l}\text { Pre-copulation and } \\
\text { copulation habits }\end{array}$ & No observations & No observations \\
\hline Date of material collecting & 14 October 2013 & 14 October 2013 \\
\hline $\begin{array}{l}\text { Date of eggs-laying/ } \\
\text { Number of eggs/Notes }\end{array}$ & $\begin{array}{l}27 \text { January } 2014,31 \text { January } 2014 \text {, the laid eggs in } \\
9 \text { clutches (each of them from } 3 \text { to } 5 \text {, mostly } 3-4 \\
\text { eggs together). Total number laid eggs }-36,15 \text { of } \\
\text { them hatched. } 112-15^{\circ} \mathrm{C}\end{array}$ & $\begin{array}{l}3 \text { November } 2013 \text { / } 4 \text { eggs, laid in clutch, sticked on } \\
\text { a lief of Platanus under a bark/ } 118.4^{\circ} \mathrm{C}\end{array}$ \\
\hline $\begin{array}{l}\text { Date of hatching/Period } \\
\text { from eggs-laying to } \\
\text { hatching }\end{array}$ & 15-20 days & 25 November $2013 / 22$ days \\
\hline $\begin{array}{l}\text { Period from offsprings to } \\
\text { adult }\end{array}$ & About 5 months (hatched February - adult in July) & No observations \\
\hline
\end{tabular}

and 1 basal tooth. Umbilicus wide. Height of Bulgarian specimens: $3.3-4.0 \mathrm{~mm}$. Diameter 10-12 $\mathrm{mm}$. Number of whorls 4.5 (Fig. 4).

Anatomy

$\lambda \bigcirc$ The atrium is relatively short and wide; $\widehat{\sigma}$ penis is cylindric-fusiform, vas-deferens enters the penis apically, penial retractor relatively wide and inserts to vas deference at small distance from penis; + vagina rather short, carrefour well visible. Length of spermatheca a little more than half of sperm oviduct. The investigated reproductive systems from the Balkan Mountains, after the town of Kotel, is typical for the species and match the descriptions of Schileyko (2006) (Fig. 5).

\section{Discussion}

According to Grossu (1983), S. diodonta occurs in the moist foliage of forests, on the bark of trees in rainy weather, and under the bark of rotten logs. Rarely even 
on the rocks. The new locality in the town of Tryavna is the first known finding of the species in an urban environment. This observation is in contrast to the current knowledge on the species' preferable localities - different type of deciduous forest (Urbanski, 1964; Grossu, 1983; Georgiev \& Stoycheva, 2007). The abundant population in the town of Tryavna shows good adaptation to the new type of habitat - open terrain with numerous shelters, keeping good shadow and moisture. For Romania, Grossu (1983) considers S. diodonta a rare species with limited distribution. According to Fehér (2020), the range of this species is far from being well studied. The new finding in an urban environment may challenge the assumption about the species narrow ecological tolerance. On the other hand, S. diodonta is rare in its entire narrow range, which is bounded to well-preserved forests in general. Such type of habitats are diminishing within its potential range (Fehér 2020). Therefore, the species is assessed as Near Threatened by the IUCN. This newly discovered population is very important because it can be a good model to investigate the ecological requirements and the survival potential of this species. A possible reason for the species rarity could be its low reproduction capacity (the small number of eggs), rather than its ecological preferences (the species survives in inappropriate urban environment).

In the sketch given by Grossu (1983), the vagina of the $S$. diodonta is too long and this drawing mistake is corrected in Schileyko (2006). The reproductive system of the Bulgarian specimens of $S$. diodonta is typical for the species - the mucus gland is missing and the vagina is short (Schileyko, 2006).

\section{Acknowledgements}

The authors thank Dr Zoltán Fehér for his helpful remarks and the botanist Chavdar Gussev for the help with habitat classification.

\section{References}

Bank R., Neubert E. 2017 Checklist of the land and freshwater Gastropoda of Europe. Last update: 16 July 2017. $170 \mathrm{pp}$.

Council Directive 92/43/EEC of 21 May 1992 on the conservation of natural habitats and of wild fauna and flora, OJ L 206, 22.7.1992, p. 7-5.
Damyanov S., Likharev I. 1975 Gastropoda terrestria. Fauna bulgarica 4: 1-425. (In Bulgarian)

EUNIS habitat classification.

Fehér Z. 2020 Soosia diodonta (amended version of 2011 assessment). The IUCN Red List of Threatened Species 2020: e.T156467A177159574. Downloaded on 27 May 2021.

Férussac A.E. d'Audebard de baron de, Deshayes G.P. 1820-1851 Histoire naturelle générale et particulière des mollusques terrestres et fluviatiles, tant des espèces que l'on trouve aujourd'hui vivantes, que des dépouilles fossiles de celles qui n'existent plus; classés d'après les caractères essentiels que présentent ces animaux et leurs coquilles. Tome premier. J.-B. Baillière, Paris, iviii, $402 \mathrm{pp}$.

Georgiev D., Stoycheva S. 2007 A new record of Soosia diodonta (Férussac, 1821) (Gastropoda: Pulmonata: Helicodontidae) in Bulgaria. Malacologica Bohemoslovaca 6: 35-37.

Grossu A.V. 1983 Gastropoda Romaniae 4, Ordo Stylommatophora, Suprafamiliile: Arionacea, Zonitacea, Ariophantacea şi Helicacea. Edit. Litera, Bucureşti, 538 pp.

Hesse P. 1918 Die Subfamilie Helicodontinae. Nachrichtsblatt der Deutschen Malakozoologischen Gesellschaft 50 (3): 99-110.

Schileyko A.A. 2006 Treatise on recent terrestrial pulmonata molluscs. Part 14. Helicodontidae, Ciliellidae, Hygromiidae. Ruthenica, Supplement 2: 1907-2047.

Soós L. 1917 Vizsgálatok a magyarországi Pulmonáták rendszertani anatomiája köréböl. Zur systematischen Anatomie der ungarischen Pulmonaten. Annales Historico-Naturales Musei Nationalis Hungarici, Budapest 15: 1-165.

Urbanski J. 1964 Beiträge zur Kenntnis balkanischer Stylommatophoren (Systematische, zoogeographiche und ökologische Studien über die Mollusken, der Balkan-Halbinsel. VII.). Bulletin de la Societe des amis des sciences et des lettres de Poznan. Série D. Sciences biologiques 4: 19-56. 